taining magnesium and ferrous sulphates as the sole source of sulphur.

2. This has demonstrated the universal importance of inorganic sulphates in the metabolism of moulds, since all species or strains tested utilized $10 \%$ or more, 56 utilized $60 \%$ or more, and 16 over $90 \%$ of the inorganic sulphate in the medium.

3. A more detailed examination of the sulphur metabolism of seven species of Penicillium, six strains of Aspergillus terreus Thom, and one strain of $A$. fumigatus Fresenius, grown on the same medium, revealed the fact that some of them form considerable amounts of 'ethereal sulphates' while others, particularly Penicillium notatum Westling, give large yields of other, probably organic, sulphur compounds, of at present unknown nature.

\title{
REFERENCES
}

Birkinshaw, J. H., Findlay, W. P. K. \& Webb, R. A. (1942). Biochem. J. 36, 526.

Bracken, A. \& Raistrick, H. (1947). Biochem. J. 41, 569.

Clutterbuck, P. W., Lovell, R. \& Raistrick, H. (1932). Biochem. J. 26, 1907.

Clutterbuck, P. W., Mukhopadhyay, S. L., Oxford, A. E. \& Raistrick, H. (1940). Biochem. J. 34, 664.
Menzel, A. E. O., Wintersteiner, O. \& Hoogerheide, J. C. (1944). J. biol. Chem. 152, 419.

Øllgaard, E. (1934). Biochem. Z. 274, 181.

Ovcharov, K. E. (1937). C.R. Acad. Sci. U.R.S.S. 16, 461.

Richards, H. M. (1897). Jb. wiss. Bot. 30, 665.

Rippel, A. \& Behr, G. (1936). Arch. Mikrobiol. 7, 584.

Woolley, D. W. \& Peterson, W. H. (1937). J.biol.Chem.122, 213.

\section{Studies on Ruminant Saliva}

\section{THE COMPOSITION AND OUTPUT OF SHEEP'S SALIVA}

\author{
By E. I. McDOUGALL, Institute of Animal Pathology, University of Cambridge
}

\section{(Received 16 October 1947)}

In all domestic animals the principal function of saliva is that of a lubricant to assist mastication and deglutition. In ruminants however, saliva has a still more important role, for the rumen has no secretion of its own and the saliva forms a fluid medium for the transport of ingesta both back to the mouth for remastication and onwards through the stomach to the small intestine. It forms also a buffered medium in which the micro-organisms of the rumen can flourish. Particular interest therefore is attached to the saliva of the ruminant, to its composition and the amounts in which it is formed.

The literature on ruminant saliva is not very extensive : except for a few more recent papers, most of it has been reviewed by Mangold (1929). The sublingual and submaxillary glands, when stimulated by eating, secrete a saliva of low ash and alkalinity which contains mucin and whose function is limited to lubricating the bolus of food. The parotid gland, on the other hand, secretes during eating and rumination, at a greater rate on the side on which the bolus is being masticated, and its flow continues at a reduced rate during the intervals of rest. The parotid saliva is formed in large amounts, it contains no ptyalin but has a high alkalinity and buffering power. It is consequently the most important secretion for the maintenance of normal rumen function.

The output of saliva by various ruminants as reported in the literature is summarized in Table 1. The quantity produced per day has been estimated at $56 \mathrm{~kg}$. for the ox by Colin (1886) and at $50 \mathrm{l}$. for the

Table 1. Published values for outputs of ruminant saliva

$\begin{array}{ll}\text { Species } & \text { Secretion } \\ \text { Ox } & \text { Parotid } \\ \text { Cow } & \text { Mixed } \\ \text { Sheep } & \text { Parotid } \\ \text { Goat } & \text { Parotid } \\ & \text { Parotid } \\ & \text { Parotid }\end{array}$

$\begin{array}{cc}\overbrace{\mathrm{ml} . / \mathrm{hr} .}^{\text {Output of saliva }} & \text { Total/day } \\ 800-2400 & 56 \mathrm{~kg} . \\ \overline{25} & 50 \mathrm{l} . \\ \begin{array}{c}3 \cdot 6-21 \cdot 6, \\ 10\end{array} & - \\ 60 & - \\ \text { * Quoted by Babkin (1944). }\end{array}$
Colin (1886)
Markoff (1913)
Scheunert \& Trautmann (1921)
Popov (1921)*
Do.
Babichev (1925)*

* Quoted by Babkin (1944). 

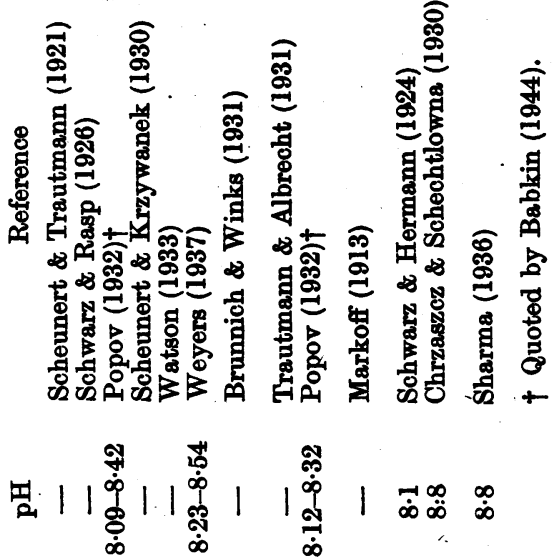

*
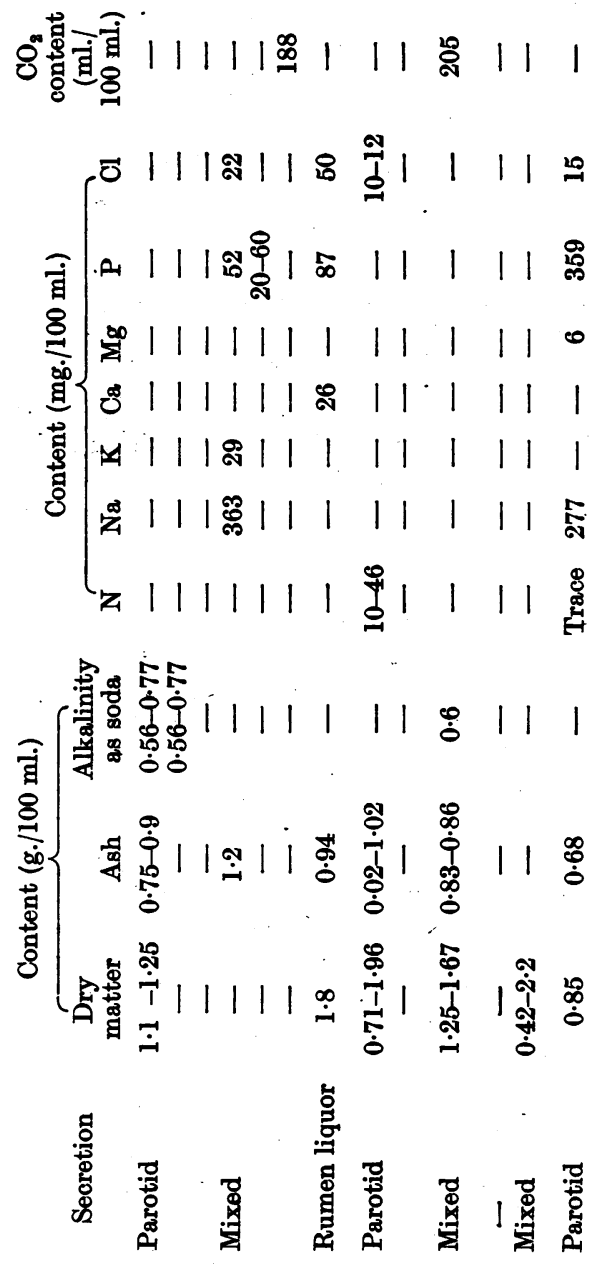

亗

严 量

울

1 总

营

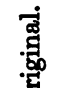

cow by Markoff (1913), the diet being hay in each case. The analyses of the saliva of various ruminants reported in the literature are given in Table 2. Zuntz (1913) claimed that the amount of alkali secreted each day in the saliva of the ox must be about six times that contained in the blood and Markoff (1913) calculated that his cow produced 300-350 g. alkali expressed as sodium bicarbonate. - The latter figure may be compared with the value of $329 \mathrm{~g}$. volatile acid (calculated as acetic acid) in the rumen and reticulum of an ox, reported by Elsden, Hitchcock, Marshall \& Phillipson (1946). It is evident that in this species the saliva flowing into the rumen each day supplies a large volume of liquid for the suspension of the ingesta and a large amount of alkali for the neutralization of acids produced in the rumen.

The analyses in Table 2 are rather incomplete, often being limited to the dry matter and titratable alkalinity. In view of the importance of the saliva to the ruminant, a more detailed knowledge of its composition seemed to be required.

In the present work a study has been made of both the mixed and parotid secretions of sheep. First, the composition was investigated by analyzing samples for dry matter, ash and various constituents, particularly inorganic ions, which might be supplied from the blood of the animal. Secondly, special attention was paid to the determination of the carbon dioxide content and the hydrogen-ion concentration. During the investigations a number of observations was also made on the rate of secretion and the daily output of saliva.

\section{METHODS}

Collection of samples. Mixed saliva was obtained either as it dripped from the tongue of a sheep under chloralose or Nembutal (pentobarbital) anaesthesia, or from a normal sheep by means of a sponge gag, Pl. $1 a$ and $b$, devised for the purpose. The samples were usually uncontaminated, though occasionally they appeared to contain small amounts of regurgitated rumen contents.

Parotid saliva was obtained by cannulating the duct from the parotid gland under Nembutal anaesthesia and leading the saliva off through valve-rubber tubing, Pl. 1 c. Collection of samples was commenced about $1 \mathrm{hr}$. after the effect of the anaesthetic had ceased and a portion was taken under paraffin oil to prevent loss of carbon dioxide for the estimation of the $\mathrm{pH}$ and carbon dioxide content.

Rumen liquor was obtained either from a sheep with a rumen fistula or from freshly killed animals. Care was taken to avoid undue exposure to air by covering with a layer of liquid paraffin, and bacterial activity was arrested by the addition of merthiolate (sodium ethylmercurithiosalicylate).

Chemical methods. The dry matter and ash were determined by pipetting $5 \mathrm{ml}$. of saliva into a small tared crucible, evaporating on a water bath and drying in a hot-air oven at $110^{\circ}$ to constant weight; finally it was ashed and weighed again. 


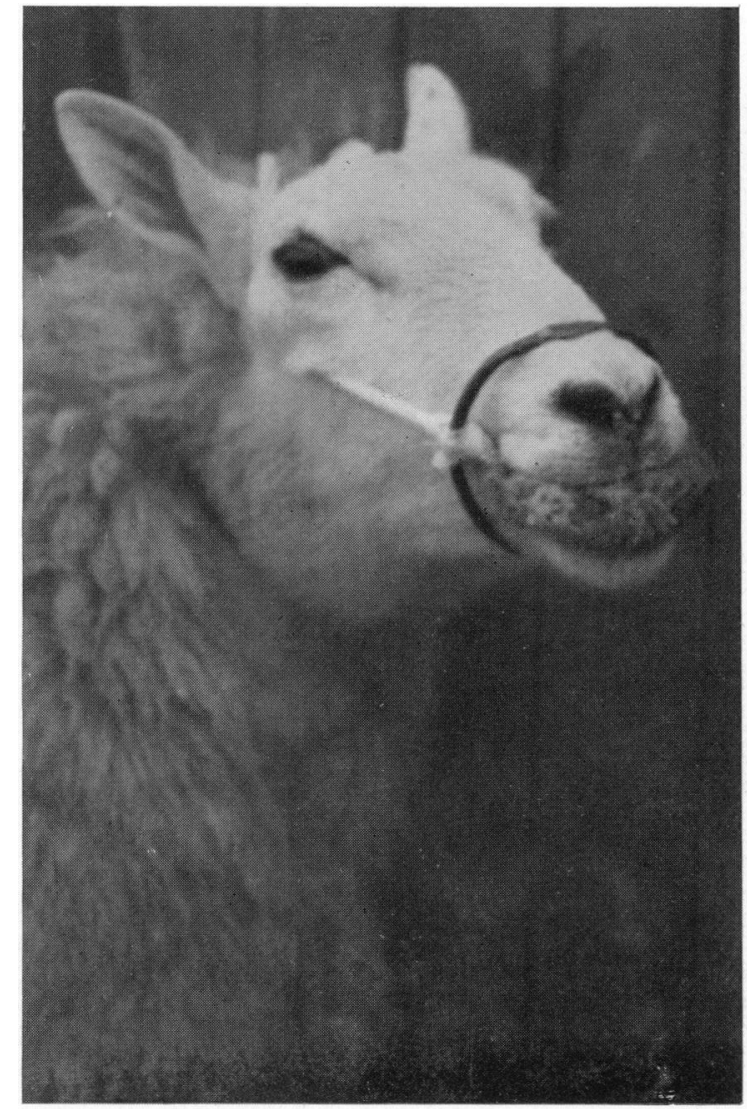

(a) Mixed saliva.

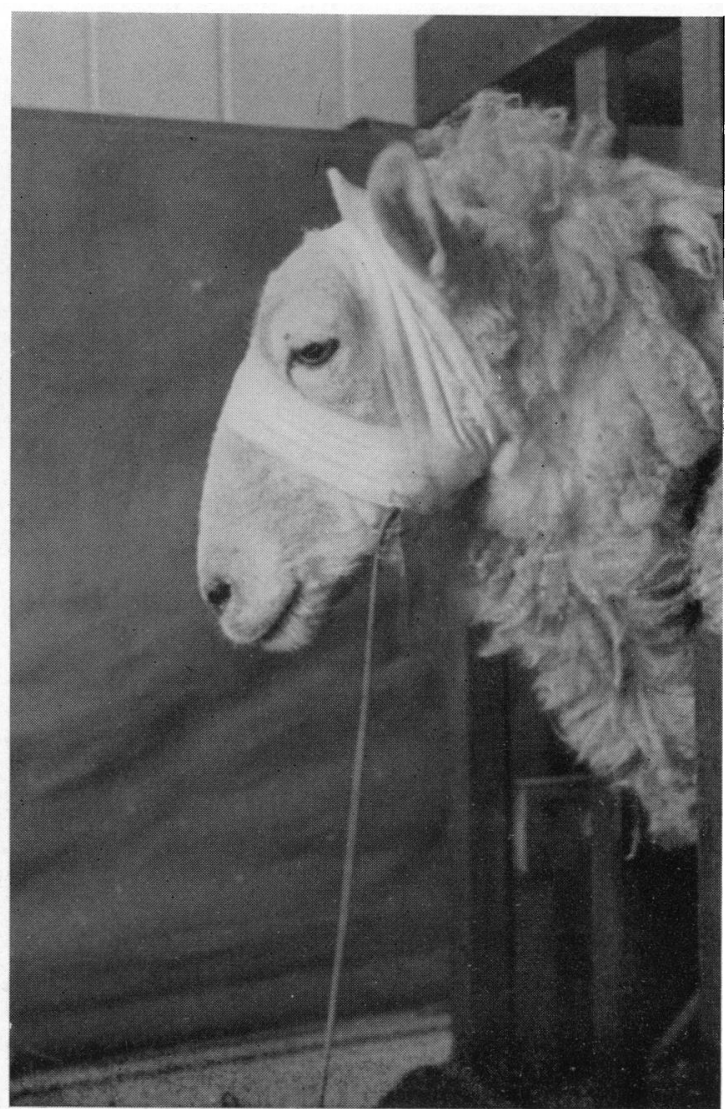

(c) Parotid saliva

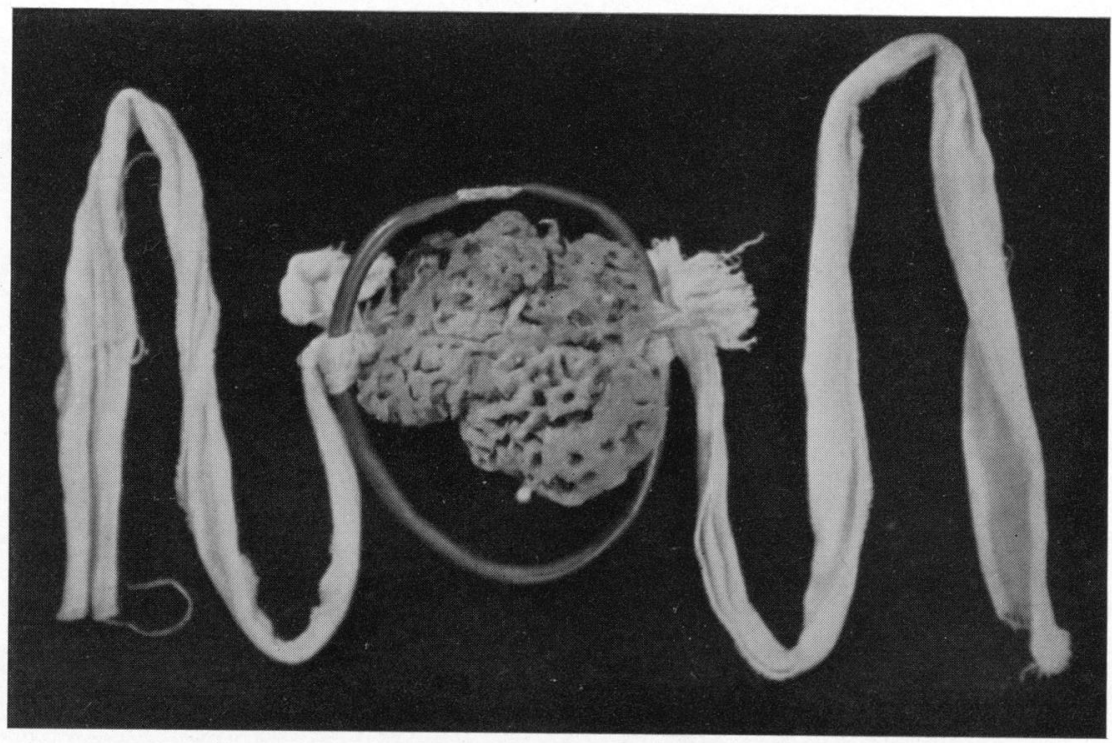

(b) Sponge gag.

E. I. McDOUGALL-Studies on RUMinant SALIVA 
Nitrogen was determined by the micro-Kjeldahl method, reducing substances by Maclean's method for blood sugar, the carbon dioxide content with Van Slyke's volumetrio apparatus, and the hydrogen-ion concentration potentiometrically using a quinhydrone electrode.

Inorganic ions were estimated by standard methods for blood serum as follows: sodium, Kramer \& Gittleman (1924); potassium, Kramer \& Tisdall (1921); calcium, Clark \& Collip (1925); magnesium, Denis (1922); phosphorus, Fiske \& Subbarow (1925); chloride, at first by the method of Whitehorn (1921) and later by the method of Sendroy (1937).

\section{RESULTS}

\section{Detailed analyses of saliva}

Mixed saliva. Eleven samples were obtained from four anaesthetized and one normal sheep. The particulars of the samples and the results of the analyses are given in Table 3.

The dry matter was $1 \cdot 0-1 \cdot 39$ and the ash $0 \cdot 73-$ $0.9 \mathrm{~g} . / 100 \mathrm{ml}$.; the organic matter was thus quite low. A small amount of nitrogen was found but its nature was not determined. No reducing sugars were detected. The chief constituents were inorganic: sodium and bicarbonate predominated; potassium, chloride and phosphate were present in smaller amounts, and calcium and magnesium were found in traces.

As the samples were not very uniform in origin they call for individual comment. With sheep 2, sample A was obtained early, and B late, in the period of anaesthesia; the analyses show, however, that a fairly steady composition was being maintained. Of the samples from sheep 3 and 4, sample $a$ appeared to contain a small amount of regurgitated rumen contents, whereas sample $b$ was uncontaminated; it is evident that the effect of this contamination was negligible.

Four samples were obtained from sheep 5 at intervals during $24 \mathrm{hr}$. by means of the sponge gag. Some constituents, notably the phosphorus and carbon dioxide, showed considerable variation during this period.

The differences in the composition of saliva from different animals were more marked for certain constituents, particularly potassium, phosphorus and carbon dioxide, than for others. These differences, however, cannot be understood without an adequate knowledge of the composition of the individual salivary secretions. Of the latter, that from the parotid gland is the most important and has therefore received special attention in this investigation.

Parotid saliva. Samples were obtained at intervals throughout the day from six sheep with parotid fistulae. Of these sheep, no. 2 and three others were wethers, no. 4 an approximately 6 months old lamb and one an aged ram. For four of the animals the experiments lasted until the third day after cannulation by which time the rate of production of saliva had become inconveniently slow. In two animals the experiments were stopped on the lst and 2nd days after cannulation respectively as the secretion had dried up and become almost negligible. At the end of the experiment one sheep had an infection of the duct but not the reduction in size and structural alteration in the gland reported by Scheunert \& Trautmann (1921) to occur some time after establishment of a parotid fistula. In two other animals examined there was no apparent reason for the stoppage of secretion; in fact, the gland subsequently healed up and was observed to function normally again.

Of the results obtained, those for two sheep only are given in Table 4 because of limitations of space. In addition to these analyses, a number of samples was examined qualitatively by the biuret, ferric chloride and Benedict tests for protein, thiocyanate and reducing sugars but all these tests proved negative.

The results for sheep 2 showed lower values for carbon dioxide content and $\mathrm{pH}$ than those for the other sheөp and are considered atypical though the reason for their being so is not apparent. The results for sheep 4 were typical of those obtained for the four remaining sheep. Only those samples collected on the first 2 days of the experiments on these five animals have been considered as normal. Those obtained on the 3rd day were excluded in taking average values because by this time the secretion was drying up as already noted and also changes in its composition had often become evident. On the whole these results showed that the composition of the parotid saliva was not affected by the age of the animals, that it was similar to that of the mixed saliva quoted in Table 3, and hence that the latter secretion was largely composed of parotid saliva.

The results for the cations do not call for much comment but those for the anions showed the following features. The phosphorus (inorganic), average $81 \mathrm{mg} . / 100 \mathrm{ml}$., showed extensive variations, both between one animal and another and among samples from the same animal. The values tended to decrease slightly when the animal was eating or ruminating and to fall gradually during the course of the experiment to a fraction of the original amount. The chloride content, average $61 \mathrm{mg}$./ $100 \mathrm{ml}$., also varied definitely from animal to animal but, on the other hand, it increased considerably during the course of the experiment; in the most extreme case, that of sheep 4, from 23 to $238 \mathrm{mg}$./ $100 \mathrm{ml}$. These two effects were approximately compensatory, as the third chief anion, the carbon dioxide content, was more steady, though in three cases there were indications of lower values setting in on the 3rd day of an experiment. Its value, average $233 \mathrm{ml} . / 100 \mathrm{ml}$., was approximately equivalent to $0.1 \mathrm{~N}$-bicarbonate solution and showed an 
圈 형

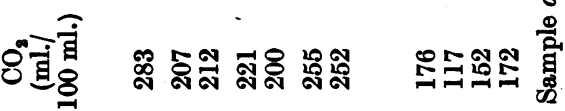

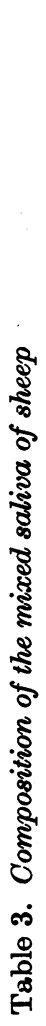

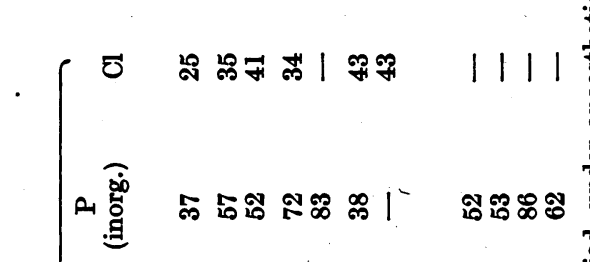

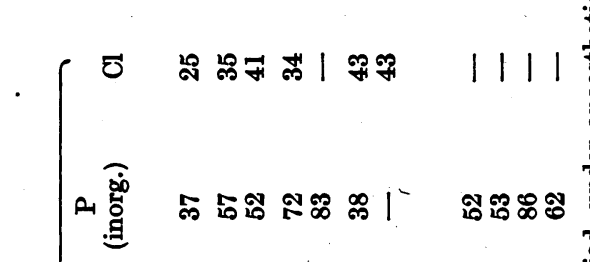

芸 $\mid \begin{aligned} & \infty \\ & \dot{0} \dot{0}\end{aligned}$

क

ठํํㄹ

4 营

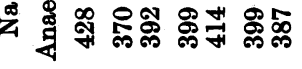
ह

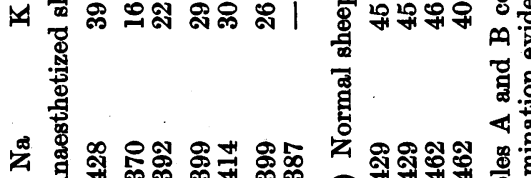

वีं

咅蓄

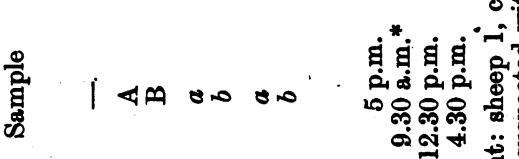

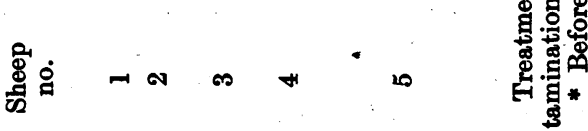

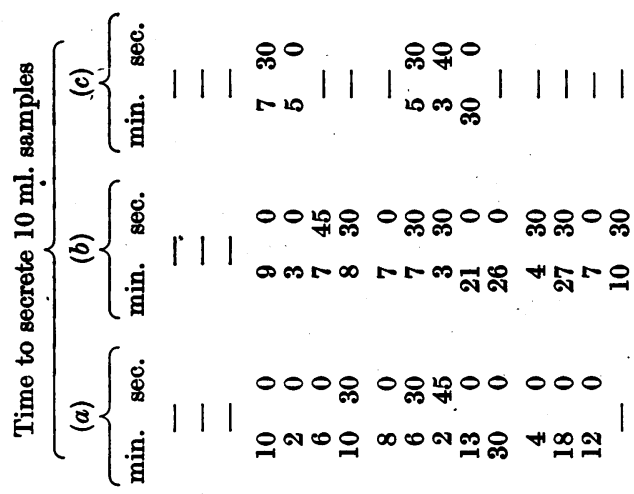

突尽|

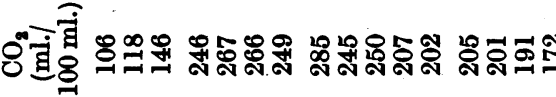

ईँ

范

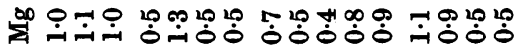
ర К|

(1) 要

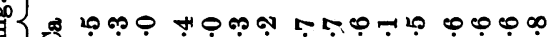
ช

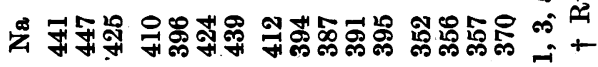

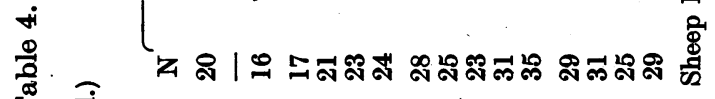
竞

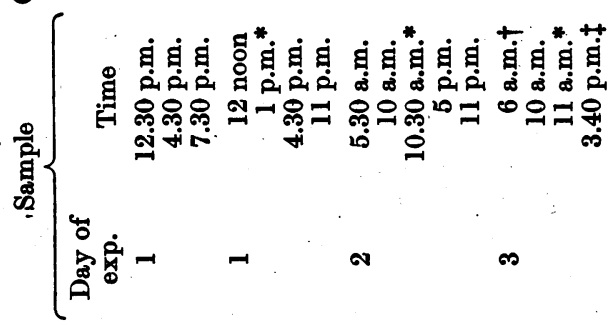

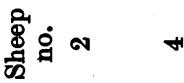


increase during eating, when the rate of secretion was also higher.

The form of phosphorus in saliva. In the analyses recorded above it was the inorganic phosphorus that was determined. To see to what extent this accounted for all the phosphorus and whether other forms were secreted from the blood, both total and inorganic phosphorus were determined in a number of samples of mixed and parotid saliva. The results indicated that, within the limits of experimental error, all of the phosphorus exists in the inorganic form.

\section{The carbon dioxide content and hydrogen-ion concentration of saliva}

The carbon dioxide content of mixed saliva. This quantity is important as it is the best indicator of the buffering power of the liquid flowing into the rumen. As it appeared from the analyses of the mixed saliva of sheep 5, Table 3, that this constituent may vary considerably throughout the day, it was decided to investigate it further. For this purpose samples of mixed saliva were collected at regular intervals during the day, from seven normal sheep, by means of the sponge gag.

At first the carbon dioxide content was determined on the samples as collected, but as the mixed secretion cannot be obtained without exposure to the air, the question arose whether the carbon dioxide content, and consequently the hydrogen-ion concentration of samples collected in this way, were representative of the original secretion. It was possible to investigate this point when studying the parotid secretion (see later). Samples were collected under liquid paraffin from five sheep from a cannula in the parotid duct. The carbon dioxide content was determined on the sample as collected. The sample was then exposed to the air overnight and the carbon dioxide content redetermined. The exposed sample was then equilibrated with human alveolar air and the carbon dioxide content measured again. The three sets of figures showed that there was usually a loss of carbon dioxide on exposure of the sample to the air, but that the initial values were restored by equilibration with human alveolar air, although no data could be found in the literature to compare the partial pressure of the carbon dioxide in the alveolar air of the sheep with that in man. The remaining samples of mixed saliva were therefore analyzed after equilibration to obtain the true value of the carbon dioxide content. Some samples were analyzed both before and after equilibration in order to determine the magnitude of the error involved in collecting the sample.

The results are given in Table 5 . The unequilibrated samples $a$ showed the same general trends as the equilibrated samples $b$ but were some 10-20\% lower. Therefore the figures given in

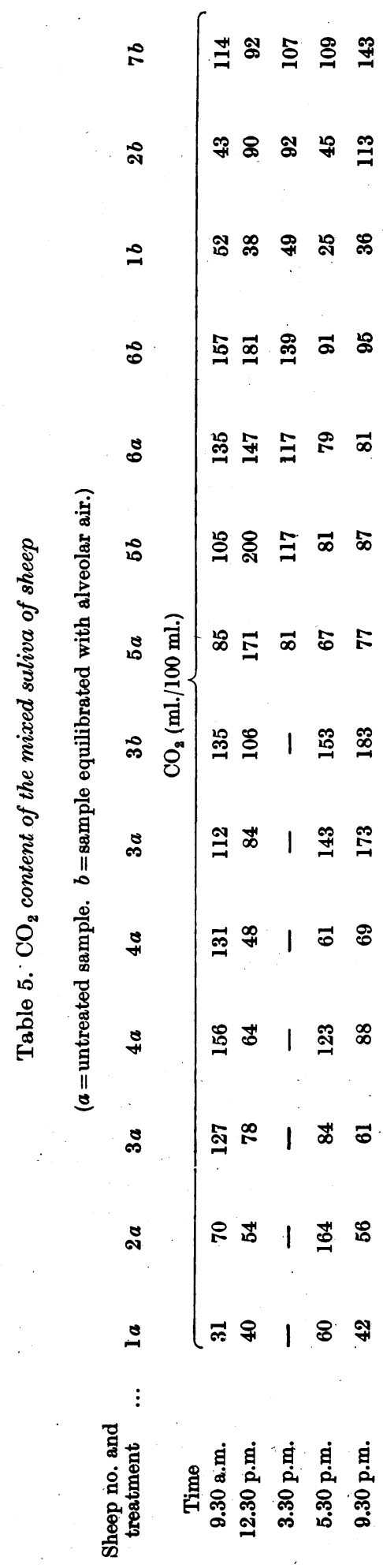


Table 3, and probably most of those hitherto reported in the literature for ruminant salive, must be regarded as indicating too low a carbon dioxide content and thus too alkaline a reaction.

The variation in the carbon dioxide content at different times of the day was often as great as $100 \%$ but was not regular enough to suggest any correlation with the time of feeding which took place after the first sample had been taken. Such a correlation might become apparent if the observations were repeated with more detailed information available about the feeding and ruminating habits of the animals. As the variation was greater than that reported in Table 4 for parotid saliva, it was probably due to changes in the proportions, rather than the composition, of the individual secretions.

The carbon dioxide conter.t of these samples was on the whole lower than was recorded for the anaesthetized sheep in Table 3; the values after equilibration showed a range of 25-200 ml./100 ml. The lowest figures were mainly due to sheep 1 and 2,* but it is not possible to say that these were definitely. abnormal owing to the small number of animals which have been studied so far. saliva is not drastically reduced on entering the rumen and is ample for its function as a buffer.

The carbon dioxide content and $\mathrm{pH}$ of parotid saliva. The number of sheep whose parotid saliva could be studied in such detail as reported in Table 4 was limited, but it was possible to obtain single samples sufficient for the determination of the carbon dioxide content and of the $\mathrm{pH}$ from seven other sheep which were being used for acute experiments under spinal anaesthesia, and thus to obtain more representative figures for these values. The results are given in the second and third columns of Table 6. The carbon dioxide content of these samples was fairly uniform (average $237 \mathrm{ml} . / 100 \mathrm{ml}$.) and of the same order as reported for sheep 4, Table 4. The average $\mathrm{pH}$ was 8.23.

\section{Rate of secretion and daily output of parotid saliva}

During the experiments on sheep with parotid cannulae, frequent observations were made on the rate of secretion of the saliva. Some of the data are included in Table 4 and some additional results are given in Table 7. Both eating and rumination

Table 6. The $\mathrm{CO}_{2}$ content and the $\mathrm{pH}$ of pure parotid saliva of sheep

\begin{tabular}{|c|c|c|c|c|}
\hline \multirow{3}{*}{$\begin{array}{l}\text { Sample from ewe } \\
\text { anaesthetized on }\end{array}$} & \multirow{3}{*}{$\begin{array}{c}\mathrm{CO}_{2} \\
\text { (ml./100 ml.) }\end{array}$} & \multicolumn{3}{|c|}{$\mathrm{pH}$} \\
\hline & & \multirow{2}{*}{$\begin{array}{l}\text { Found, } \\
\text { at room } \\
\text { temperature }\end{array}$} & \multicolumn{2}{|c|}{ Calculated, for } \\
\hline & & & $15^{\circ}$ & $38^{\circ}$ \\
\hline $\begin{array}{c}\text { 24. i. } 44 \\
\text { 26. i. } 44 \\
\text { 29. i. } 44 \\
\text { 2. ii. } 44 \\
\text { 29. ii. } 44 \\
\text { 1. iii. } 44 \\
\text { 3. iii. } 44\end{array}$ & $\begin{array}{l}277 \\
241 \\
253 \\
227 \\
176 \\
254 \\
232\end{array}$ & $\begin{array}{l}8 \cdot 30 \\
8 \cdot 46 \\
8 \cdot 23 \\
8 \cdot 05 \\
8 \cdot 11 \\
8 \cdot 14 \\
8 \cdot 35\end{array}$ & $\begin{array}{l}8 \cdot 26 \\
8 \cdot 20 \\
8 \cdot 22 \\
8 \cdot 17 \\
8 \cdot 06 \\
8 \cdot 22 \\
8 \cdot 18\end{array}$ & $\begin{array}{l}8 \cdot 16 \\
8 \cdot 10 \\
8 \cdot 12 \\
8 \cdot 07 \\
7 \cdot 96 \\
8 \cdot 12 \\
8 \cdot 08\end{array}$ \\
\hline Average & 237 & $8 \cdot 23$ & $8 \cdot 19$ & 8.09 \\
\hline
\end{tabular}

On flowing into the rumen, the mixed saliva becomes diluted with the food and water of the diet and partly neutralized by the acids produced by fermentation in the rumen. The carbon dioxide content of the rumen liquor may therefore be expected to show considerable variation in relation to the diet of the animal and the time since feeding. However, a few samples of rumen liquor were analyzed for comparison with the mixed saliva. The results showed values of $40-170 \mathrm{ml} . / 100 \mathrm{ml}$. from which it appears that the bicarbonate content of the mixed

* Sheep 2, Table 4 and sheep 1 and 2, Table 5, had well established rumen fistulas. As the carbon dioxide content of the saliva from these animals was particularly low, one wonders whether the rumen fistulas had made them abnormal in this respect. Sheep 6, Table 4, however, possessed a rumen fistula for years but it had become closed at the time of the salivary studies; the saliva of this sheep had a normal carbon dioxide content. brought about a considerable increase in the rate of secretion. The mere sight of food, on the other hand, caused no psychological stimulation. The effect of pilocarpine was not apparent until $30 \mathrm{mg}$. had been given intravenously. When 5 grains Nembutal was given intravenously, this was sufficient to cause the sheep to stagger on its feet, but appeared to have only a transient effect on the rate of secretion.

It was possible in these experiments to collect the saliva from the cannulated parotid of some of the sheep for considerable periods and thus to obtain a reliable estimate of the daily output. The results are summarized in Table 8. The volume from one gland was 930-1840 (average 1310) ml./24 hr. At slaughter of sheep 6, Table 8, the cannulated parotid gland was found to weigh $35 \mathrm{~g}$. As it secreted $930 \mathrm{ml}$. in $24 \mathrm{hr}$., its activity can be expressed as $27 \mathrm{ml} . / 24 \mathrm{hr}$./g. of tissue. 
Table 7. Observations on the rate of parotid secretion in the sheep

Time to secrete $10 \mathrm{ml}$ samples

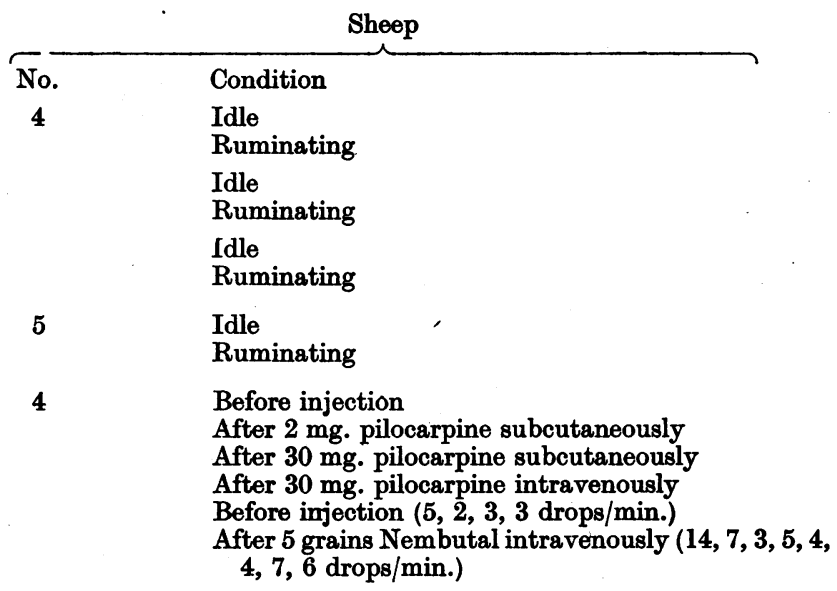

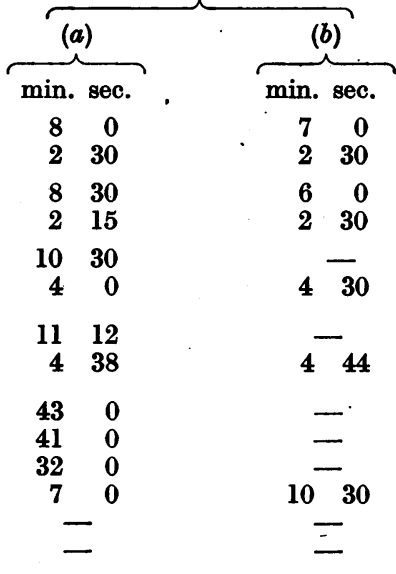

Table 8. Volume of saliva collected from a paratid gland of sheep

$\begin{array}{cc}\text { Sheep no. } & \text { ml. } / 24 \mathrm{hr} . \\ 1 & 1100 \\ 3 & 1440 \\ 4 & 1840 \\ 5 & 1240 \\ 6 & 930 \\ \text { Average } & 1310\end{array}$

\section{DISCUSSION}

\section{Mixed saliva}

Comparison with human saliva. The special importance of saliva to the ruminant was emphasized in the introduction. It is therefore relevant to compare the present results for sheep with those for an animal with a simple stomach. To this end, figures quoted for the composition of mixed human saliva in a number of text-books are presented in Table 9, together with the range of the data given in Table 3. The saliva of sheep has less dry matter and calcium, a higher ash, sodium, carbon dioxide content and $\mathrm{pH}$ and about the same level of magnesium and chloride, as compared with human saliva. The potassium and chloride are variable in both.
Relation to function. These differences in composition are clearly related to the special role of sheep's saliva. The large amount of carbon dioxide as bicarbonate together with the high phosphate content are functionally most important for rendering the fluid an ideal buffer for the bacterial digestion that goes on in the rumen. The bicarbonate secreted each day by the parotids can be calculated from the present data to be on the average 2.73 equiv. This may be compared with a total of $63.6 \mathrm{~g}$. (1.05 equiv.) of volatile acids, as acetic acid, found in the rumen of sheep by Elsden et al. (1946). The salivary phosphate may have a function in addition to that of a buffer, as it was suggested by Watson (1933) that it might be important in maintaining the bacterial population of the rumen. This may. well be the case as van der Wath (1942) showed that the number of these organisms was stimulated by a supplement of phosphate to a diet low in this constituent.

\section{Parotid saliva}

Typical composition. The results obtained in the experiments on sheep with cannulated parotid ducts (see Table 4) have been averaged to give a typical composition for the sheep's parotid saliva shown in Table 10. In arriving at this, the data obtained on

Table 9. Comparison of the composition of mixed saliva of sheep and of man

\begin{tabular}{|c|c|c|c|c|c|c|c|c|c|c|c|}
\hline \multirow[b]{3}{*}{ Animal } & \multirow{3}{*}{$\begin{array}{l}\text { Literature } \\
\text { reference }\end{array}$} & \multicolumn{2}{|c|}{$\begin{array}{c}\text { Content } \\
\text { (g./100 ml.) }\end{array}$} & \multirow{2}{*}{\multicolumn{6}{|c|}{ Content (mg./100 ml.) }} & \multirow{3}{*}{$\begin{array}{c}\mathrm{CO}_{2} \\
\text { (ml./ } \\
100 \mathrm{ml} .)\end{array}$} & \\
\hline & & & & & & & & & & & \\
\hline & & matter & Ash & $\mathrm{Na}$ & $\mathbf{K}$ & $\mathrm{Ca}$ & $\mathbf{M g}$ & $\mathbf{P}$ & Cl & & pH \\
\hline Sheep & - & $1.0-1.4$ & $0.7-0.9$ & $370-462$ & $16-46$ & $1 \cdot 6-3 \cdot 0$ & $0 \cdot 6-1 \cdot 0$ & 37-72 & $25-43$ & $117-283$ & $8 \cdot 4-8.7$ \\
\hline $\begin{array}{l}\text { Man } \\
\text { Man } \\
\text { Man }\end{array}$ & $\begin{array}{l}\text { (Thorpe, 1938) } \\
\text { (Shohl, 1939) } \\
\text { (Fearon, 1946) }\end{array}$ & $\frac{0.3-1 \cdot 4}{0.6}$ & $\begin{array}{l}0.2 \\
0.219 \\
-\end{array}$ & $\begin{array}{c}26 \\
20 \\
20-30\end{array}$ & $\begin{array}{c}38 \\
100 \\
30-100\end{array}$ & $\begin{array}{l}8 \\
6 \\
8\end{array}$ & $\begin{array}{l}1 \\
2 \\
1\end{array}$ & $\begin{array}{c}10 \\
18 \\
3-19\end{array}$ & $\begin{array}{c}50 \\
40 \\
40-50\end{array}$ & $\underset{22-33}{-}$ & $\begin{array}{c}\overline{6 \cdot 6} \\
6 \cdot 35-6 \cdot 85\end{array}$ \\
\hline
\end{tabular}


the 3rd day of the experiments and all those for sheep 2 were excluded for reasons already stated (p. 101). The composition is expressed as $\mathrm{mg} . / 100 \mathrm{ml}$. and m-equiv./l. In calculating the latter, it has been assumed that at the $\mathrm{pH}$ of the saliva, the carben dioxide exists as $\mathrm{HCO}_{3}^{-}$and the phosphorus as $\mathrm{HPO}_{4}^{=}$. total carbon dioxide content and the partial pressure of the carbon dioxide, provided the composition of the solution is known. The hydrogen-ion concentrations of the samples of saliva in Table 6 were therefore calculated from the carbon dioxide content (1) at room temperature for comparison with the values actually found and (2) at body temperature

Table 10. Average composition of the parotid saliva of sheep

$\overbrace{\begin{array}{c}\text { Dry } \\ \text { matter } \\ 1.28\end{array}}^{\text {Content }} \begin{gathered}\text { Ash } \\ 0.97\end{gathered}$

\begin{tabular}{|c|c|c|c|c|c|c|c|}
\hline \multicolumn{7}{|c|}{ Content (mg./100 ml.) } & $\mathrm{CO}_{2}$ \\
\hline $\mathbf{N}$ & $\mathrm{Na}$ & $\mathbf{K}$ & $\mathrm{Ca}$ & $\mathrm{Mg}$ & $\mathbf{P}$ & $\mathrm{Cl}$ & $100 \mathrm{ml}$.) \\
\hline 20 & 408 & 32 & 0.8 & $0 \cdot 8$ & 81 & 61 & 233 \\
\hline \multicolumn{8}{|c|}{ Content (m-equiv./1.*) } \\
\hline
\end{tabular}

* P assumed to exist as $\mathrm{HPO}_{4}-\mathrm{CO}_{2}$ assumed to exist as $\mathrm{HCO}_{3}-$. Total cations, 186; total anions, 173 m-equiv.

Completeness of the analyses. The amounts of the various ions given in Table 10 can be calculated to be equivalent to a dry matter content of 1.29 g. $/ 100 \mathrm{ml}$. This figure is in good agreement with the average dry matter actually found, viz. $1 \cdot 28$ g./100 ml., and indicates that no major constituent had been overlooked. On the other hand, when the results are expressed as m-equiv., it is apparent that the total cations, 186 m-equiv./l., exceed the total anions, $173 \mathrm{~m}$-equiv./l. This difference might be accounted for as sulphate which exists in small amounts in the blood or as volatile acids which were shown by Barcroft, McAnally \& Phillipson (1944) to occur in the blood of the ruminant, though the amount found in arterial blood was very small. Another possibility might be the presence of an organic acid, such as lactic acid, derived from the metabolism of the gland itself. The present results, however, are sufficient to enable one to suggest a formula for synthetic saliva which may prove useful to biochemists and bacteriologists wishing to simulate the conditions in the rumen of the sheep in the study of ruminant digestion. Such a formula is given in Table 11, and is based on the data in Table 10.

\section{Table 11. Suggested composition for synthetic saliva}

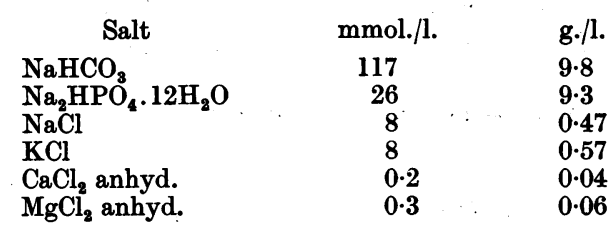

Hydrogen-ion concentration. The saliva was found by potentiometric determinations to have $\mathrm{a} \mathbf{p H}$ of c. 8.23 (Table 6), due to the large amount of bicarbonate present. The hydrogen-ion concentration may be calculated indirectly in such a solution from the to give the reaction of the saliva as secreted. The steps in the calculations, the assumptions made and the values taken for the various constants are given below.

An approximate value of the ionic strength $(\mu)$ of the saliva was calculated, assuming the typical composition given in Table 10, whence

$$
\mu=\frac{1}{2} \Sigma m_{i} z_{i}^{2}=0 \cdot 18,
$$

where $m_{i}=$ molar concentration of an individual ion and $z_{i}$ its valency.

The first apparent stoicheiometric dissociation constant of carbonic acid at this ionic strength was calculated from the thermodynamic ionization constant. The simplified DebyeHückel equation for uni-univalent electrolytes in dilute solutions gives the relation of these three quantities as

$$
\mathrm{pK}^{\prime}=\mathrm{pK}-A \sqrt{ } \mu,
$$

in which $A$ is a constant for a given solvent. This equation was found by Hastings \& Sendroy (1925) to hold for carbonic acid in solutions containing sodium bicarbonate and chloride. As the predominating ionic species in saliva are sodium and bicarbonate and as Bray (1925) found that the activity of the bicarbonate ion is different in solutions of potassium as compared with sodium salts, the above equation was employed in the present calculations, rather than any more recent but empirical equation based on measurements made with potassium salts. Values for $\mathrm{pK}_{1}$ at the two required temperatures were taken from Shedlovsky \& MacInnes (1935) and for $A$ from MacInnes (1939). Then for carbonic acid in saliva:

$$
\begin{aligned}
& \text { at } 18^{\circ}, \mathrm{pK}_{1}^{\prime}=6.43-0.50 \sqrt{ } 0.18=6.22, \\
& \text { at } 38^{\circ}, \mathrm{pK}_{1}^{\prime}=6.32-0.52 \sqrt{0} \cdot 18=6 \cdot 10 .
\end{aligned}
$$

- Before the $\mathrm{pH}$ of the saliva can be calculated it is necessary to know the value $\left[\mathrm{H}_{2} \mathrm{CO}_{3}\right]$, representing the concentration of unionized carbonic acid and physically dissolved carbon dioxide, a value depending on the carbon dioxide tension. As no data could be found in the literature for the carbon dioxide tension of sheep's saliva, blood or alveolar air, the value for human arterial blood was taken, giving

$$
\left[\mathrm{H}_{2} \mathrm{CO}_{3}\right]=2 \cdot 4 \mathrm{ml} . / 100 \mathrm{ml} \text {. }
$$


This seemed justified for two reasons: (1) It has been shown that equilibration with human alveolar air restored the original carbon dioxide content to samples of sheep's saliva which had lost carbon dioxide through exposure to air. The differences in the partial pressure of carbon dioxide in the two species cannot therefore be very great. (2) Small differences between the assumed and actual values of $\left[\mathrm{H}_{2} \mathrm{CO}_{3}\right]$ will have only a small effect on the calculated $\mathrm{pH}$ values.

The $\mathrm{pH}$ of the samples of saliva were calculated from their carbon dioxide content given in Table 6, employing the Henderson-Hasselbach equation, viz.

$$
\mathrm{pH}=\mathrm{pK}^{\prime}+\log [\text { Salt }] /[\text { Acid }] \text {. }
$$

This becomes, when applied to the sheep's parotid saliva:

$$
\begin{array}{ll}
\text { at } 15^{\circ}, & \mathrm{pH}=6 \cdot 22+\log \left[\text { Total } \mathrm{CO}_{2}-2 \cdot 4\right] /[2 \cdot 4] \\
\text { at } 38^{\circ}, & \mathrm{pH}=6 \cdot 10+\log \left[\text { Total } \mathrm{CO}_{2}-2 \cdot 4\right] /[2 \cdot 4]
\end{array}
$$

The calculated $\mathrm{pH}$ values at 15 and $38^{\circ}$ are given in Table 6 together with the experimental data on these samples. It will be seen that the calculated values at $15^{\circ}$ are in good agreement with those found potentiometrically at room temperature, the averages being 8.19 and 8.23 , respectively. The calculated values at $38^{\circ}$ show that the saliva is secreted at a pH of about $8 \cdot 1$. This value is less alkaline than many reported for ruminant saliva but is considered more accurate.

Calcium. The saliva of the sheөp contains much less calcium than the blood. This is probably because in the absence of significant amounts of protein the calcium must be largely ionized and at the $\mathrm{pH}$ of the saliva only small amounts of calcium ions can be in equilibrium with the carbonate and phosphate present. The maximum ionized calcium possible at body temperature was calculated for a solution with the composition of sheep's parotid saliva, as follows :

The concentration of the carbonate ion was obtained from an equation derived from the negative logarithmic expressions for the first and second stages of ionization of carbonic acid:

$$
\begin{aligned}
& \mathrm{pK}_{1}^{\prime}=\mathrm{pH}+\mathrm{p}\left[\mathrm{HCO}_{3}^{-}\right]-\mathrm{p}\left[\mathrm{H}_{2} \mathrm{CO}_{3}\right] \\
& \mathrm{pK}_{2}^{\prime}=\mathrm{pH}+\mathrm{p}\left[\mathrm{CO}_{3}^{-}\right]-\mathrm{p}\left[\mathrm{HCO}_{3}^{-}\right] .
\end{aligned}
$$

Adding (i) and (ii) and rearranging :

$$
\mathrm{p}\left[\mathrm{CO}_{3}=\right]=\mathrm{pK}_{1}^{\prime}+\mathrm{pK}_{2}^{\prime}-2 \mathrm{pH}+\mathrm{p}\left[\mathrm{H}_{2} \mathrm{CO}_{3}\right] \text {. }
$$

The values $\mathrm{pK}_{1}{ }^{\prime}=6 \cdot 10$ at $38^{\circ}$ and $\mu=0 \cdot 18$ have already been calculated. The value of $\mathrm{pK}_{2}^{\prime}$ under these conditions was obtained from the equation of Hastings \& Sendroy (1925):

$$
\mathrm{pK}_{2}^{\prime}=10 \cdot 22-1 \cdot 1 \sqrt{\mu}=9 \cdot 75 \text {. }
$$

The $\mathrm{pH}$ was taken as $8 \cdot 1$ and the apparent concentration of unionized carbonic acid again assumed to be $2.4 \mathrm{ml} . / 100 \mathrm{ml}$. The latter expressed as molar quantities gives

$$
\left[\mathrm{H}_{2} \mathrm{CO}_{3}\right]=1.07 \times 10^{-3} \text {, }
$$

and therefore $\mathrm{p}\left[\mathrm{H}_{2} \mathrm{CO}_{3}\right]=2 \cdot 97$. Substituting these values in equation (iii) gives

$$
\mathrm{p}\left[\mathrm{CO}_{3}{ }^{-}\right]=6 \cdot 10+9 \cdot 75-2 \times 8 \cdot 1+2 \cdot 97=2 \cdot 62 .
$$

The equilibrium concentration of calcium ions corresponding to this amount of carbonate was calculated from

the solubility product of calcium carbonate. The value of the latter at $38^{\circ}$ was taken from Sendroy \& Hastings (1927a):

$$
\begin{aligned}
& \mathrm{pK}_{\text {s.p. }}^{\prime}=8.58-\frac{4.94 \sqrt{\mu}}{1+1.85 \sqrt{ } \mu}=7 \cdot 40 \text { at } \mu=0.18 \text {. } \\
& \text { Then } \quad \mathrm{p}\left[\mathrm{Ca}^{++}\right]=\mathrm{pK} \text { s.p. }-\mathrm{p}\left[\mathrm{CO}_{3}{ }^{\prime}\right] \\
& =7 \cdot 40-2 \cdot 62=4 \cdot 78 \text {. } \\
& \text { Whence } \quad\left[\mathrm{Ca}^{++}\right]=1.7 \times 10^{-5} \\
& =0.07 \mathrm{mg} . / 100 \mathrm{ml} \text {. }
\end{aligned}
$$

A series of similar calculations was made for tertiary calcium phosphate, employing the values for the three dissociation constants of phosphoric acid and the solubility product of the calcium salt, given by Sendroy \& Hastings $(1927 a, b)$. The equilibrium concentration of the calcium ion with the phosphate concentration found in saliva was found to be $\left[\mathrm{Ca}^{++}\right]=0 \cdot 1 \mathrm{mg} \cdot / 100 \mathrm{ml}$.

It follows from the above considerations that the low salivary calcium is secondary to the high bicarbonate and phosphate contents. The values actually found are higher than the calculated figures. One can only speculate whether the discrepancy is due to experimental error in determining the small amount present, to the existence of colloidal calcium phosphate, to supersaturation or to an undissociated complex.

Comparison with sheep's serum. As the dry matter of the parotid saliva of sheep is largely mineral and the mineral constituents of such secretions must be derived from the blood, it is interesting to see how the mineral compositions of these two fluids compare. The average composition of the parotid saliva has therefore been presented in Table 12 together with figures for the composition of sheep's serum.

\section{Table 12. Comparison of the composition of parotid saliva and serum of sheep}

\section{Constituent}

Dry matter (g./100 ml.)

Nitrogen (mg./100 ml.)

Reducing sugars (mg./100 ml.)

$\mathrm{Na}(\mathrm{mg} . / 100 \mathrm{ml}$.)

$\mathrm{K}$ (mg./100 ml.)

$\mathrm{Ca}(\mathrm{mg} . / 100 \mathrm{ml}$.)

$\mathrm{Mg}$ (mg./100 ml.)

$\mathrm{P}$ (inorganic) (mg./100 ml.)

$\mathrm{Cl}$ (mg./100 ml.)

$\mathrm{CO}_{2}$ (ml. $/ 100 \mathrm{ml}$.)

* From Shearer \& Stewart (1931); remainder from Dukes (1943).

The concentrations of the principal cations, sodium and potassium, are similar in both fluids. The concentrations of both calcium and magnesium are less in the saliva. The greatest differences, how ever, are shown by the anions. The carbon dioxide content of the saliva is about four times the normal alkali reserve of sheep's blood. It might be expected that the continuous loss of so much alkali from the 
blood as bicarbonate would tax the ability of the sheep to maintain the acid-base balance in the blood. This loss, however, may be offset not only by reabsorption lower down in the digestive tract but also by the abomasal secretion which in the sheep is not only acid but also continuous. The phosphorus of saliva is entirely inorganic, variable in amount and has a concentration about fifteen times that of the serum inorganic phosphorus. This is in agreement with the data of Watson (1933) who found in addition that the phosphorus in the saliva appeared to depend on the inorganic phosphorus in the serum. The chloride occurs to about one-sixth of the extent of its normal level in the serum.

Nature of the secretion. It is evident from Table 12 that the parotid gland mainly secretes ionized salts. This suggests that the difference between the ionic composition of serum and saliva might be due to a Donnan effect of the serum proteins. However, it is evident by inspection of the data that the required relation for uni-univalent electrolytes, namely,

$$
[\text { Base }][\text { Acid }]_{\text {saltra }}=[\text { Base }][\text { Acid }]_{\text {Serum }}
$$

does not hold. Hence saliva cannot be regarded as a transudate in equilibrium with the blood.

If the two fluids are in static equilibrium, the general condition must hold that there is no net gain or loss of free energy involved in the formation of the saliva. Assuming that all the constituents of the latter are derived from the serum, the associated change in free energy can be calculated without making any assumptions as to the mechanism of saliva formation.

The decrease in free energy, $-\Delta F$, for $1 \mathrm{l}$. of saliva is given by the expression

$$
-\Delta F=\Sigma n R T \log _{e}\left(a_{\text {eerum }} / a_{\text {eallva }}\right),
$$

where $n$ is the number of mol. of a constituent transferred from a very large volume of serum to 11 . of saliva and $a$ its activity. The ratios of the activities can be sufficiently approximated by the ratios of the molar concentrations. In calculating the latter, the median value has been employed for those serum constituents for which a range only has been quoted in Table 12. Serum calcium has been assumed to be $60 \%$ ionized. Phosphate in the saliva has been regarded as entirely $\mathrm{HPO}_{4}-$ and the proportion existing in this form in the serum has been calculated for $\mathrm{pH} 7.4$ using the expression of Hastings \& Sendroy (1927a) for $\mathrm{pK}_{\mathrm{z}}^{\prime}$ of phosphoric acid. The work of transference of other phosphate ions has been taken as negligible.

In this way it is estimated that

$$
-\Delta F=-130-163=-293 \mathrm{cal} \text {; }
$$

the first term refers to the transference of salts and the second to the transference of water. The saliva is therefore not a dialysate in equilibrium with serum as its formation requires a small but definite supply of energy. Whether this can be obtained from the work of ultrafiltration done on the saliva or whether it must be supplied through the metabolism of the gland itself is a problem for further investigation.

\section{SUMMARY}

1. The composition of the mixed and parotid salivary secretions of the sheep has been studied.

2. The dry matter, $1.0-1.4 \mathrm{~g} . / 100 \mathrm{ml}$., of both fluids was mainly inorganic but contained small amounts of nitrogen, $9-36 \mathrm{mg} . / 100 \mathrm{ml}$. The mixed secretion usually appeared to consist largely of parotid saliva. The concentrations of total salts in the latter, $180 \mathrm{~m}$-equiv./l., and of the principal cations, sodium and potassium, were similar to those occurring in serum. The concentrations of the anions, of bicarbonate, and of phosphate and chloride, were approximately four times, fifteen times and onesixth respectively as much as those obtained in the serum.

3. The carbon dioxide content of the parotid saliva, mixed secretion and rumen liquor was found to be 233, 25-200 and $40-170 \mathrm{ml} . / 100 \mathrm{ml}$., respectively. The parotid saliva had an average $\mathrm{pH}$ of 8.2 and was calculated to be actually secreted with a $\mathrm{pH}$ of $8 \cdot 1$.

4. The amount of saliva formed by a single parotid gland ranged from 930 to $1840 \mathrm{ml}$. in $24 \mathrm{hr}$.

I must thank Dr A. T. Phillipson, Unit of Animal Physiology, Cambridge, for cannulating the parotid ducts of the experimental animals and for his continued help and encouragement in this investigation.

\section{REFERENCES}

Babkin, B. P. (1944). Secretory Mechanism of the Digestive Glands, p. 177. New York: Hoeber.

Barcroft, J., McAnally, R. A. \& Phillipson, A. T. (1944). J. exp. Biol. 20, 120.

Bray, W. C. (1925). Dissertation. Yale University. Quoted by Hastings, A. B., Murray, C. D. \& Sendroy, J. Jr. (1927). J. biol. Chem. 71, 723.

Brunnich, J. C. \& Winks, W. R. (1931). Qd agric. J. 35, 183. Chrzaszcz, T. \& Schechtlowna, Z. (1930). Biochem. Z. 219, 30.

Clark, E. P. \& Collip, J. B. (1925). J. biol. Chem. 63, 461.
Colin, G. C. (1886). Treatise on the Comparative Physiology of Domestic Animals, 1, 3rd ed. Paris: J. B. Baillière and Sons.

Denis, W. (1922). J. biol. Chem. 52, 411.

Dukes, H. H. (1943). Physiology of Domestic Animals, 5th ed., p. 45. Ithaca, N.Y.: Comstock.

Elsden, S. R., Hitchcock, M. W. S., Marshall, R. A. \& Phillipson, A. T. (1946). J. exp. Biol. 22, 191.

Fearon, W. R. (1946). An Introduction to Biochemistry, 3rd ed., p. 300. London: Heinemann.

Fiske, C. H. \& Subbarow, Y. (1925). J. biol. Chem. 66, 375. 
Hastings, A. B. \& Sendroy, J. Jr. (1925). J. biol. Chem. 65, 445.

Kramer, B. \& Gittleman, I. (1924). J. biol. Chem. 62, 353.

Kramer, B. \& Tisdall, F. F. (1921). J. biol. Chem. 46, 339.

MacInnes, D. A. (1939). The Principles of Electrochemistry, p. 144. New York: Reinhold.

Mangold, E. (1929). Handbook of Nutrition and Metabolism of Domesticated Animals. 2. Digestion and Excretion, p. 113. Berlin: Julius Springer.

Markoff, J. (1913). Biochem. Z. 57, 1.

Scheunert, A. \& Trautmann, A. (1921). Pflüg. Arch. ges. Physiol. 193, 33.

Scheunert, A. \& Krzywanek, Fr. W. (1930). Pflüg. Arch. ges. Physiol. 223, 472.

Schwarz, C. \& Hermann, B. (1924). Pfüg. Arch. ges. Physiol. $202,475$.

Schwarz, C. \& Rasp, F. (1926). Fermentforschung, 8, 50.

Sendroy, J. Jr. (1937). J. biol. Chem. 120, 405.

Sendroy, J. Jr. \& Hastings, A. B. (1927a). J. biol. Chem. 71, 783.
Sendroy, J. Jr. \& Hastings, A. B. (1927b). J. biol. Chem. 71, 797.

Sharma, G. K. (1936). Indian vet. J. 6, 266.

Shearer, G. D. \& Stewart, J. (1931). Rep. Inst. anim. Path. Univ. Camb., no. 2, p. 121.

Shedlovsky, T. \& MacInnes, D. A. (1935). J. Amer. chem. Soc. 57, 1705.

Shohl, A. T. (1939). Mineral Metabolism, p. 62. New York: Reinhold.

Thorpe, W. V. (1938). Biochemistry for Medical Students, p. 187. London: Churchill.

Trautmann, A. \& Albrecht, H. (1931). Arch. wiss. prakt. Tierheilk. 64, 93.

van der Wath, J. G. (1942). Thesis. University of Pretoria.

Watson, R. H. (1933). Aust. J. biol. med. Sci. 11, 67.

Weyers, H. (1937). Inaugural Dissertation. University of Berlin.

Whitehorn, T. C. (1921). J. biol. Chem. 45, 449.

Zuntz, H. (1913). Naturwissenschaften, 1, 7.

\title{
Studies in Vitamin A
}

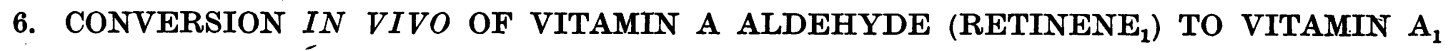

\author{
By J. GLOVER, T. W. GOODWIN AND R. A. MORTON \\ Department of Biochemistry, University of Liverpool
}

(Received 19 December 1947)

Retinene $_{1}$ is a fairly stable protein-free substance first obtained from rhodopsin (visual purple), the photolabile chromoprotein of the dark-adapted retina. It has recently been shown to be the aldehyde of vitamin $A_{1}$ (Morton \& Goodwin, 1944; Ball, Goodwin \& Morton, 1948). Chemical methods for its preparation have been described (Hunter \& Hawkins, 1944; van Dorp \& Arens, 1947), and a very simple method, in which a solution of vitamin $\mathbf{A}_{1}$ alcohol in light pétroleum is left to stand over powdered pyrolusite in the cold (Ball et al. 1948), has made it easily accessible.

The present paper is concerned with the fate of retinene ${ }_{1}$ when presented to body tissues other than the retina. In particular, it was desired to find out whether it possessed per se vitamin $A_{1}$ activity. The substance, in a preparation containing no detectable vitamin $A_{1}$ but some $75 \%$ of retinene $\theta_{1}$, has been administered orally and parenterally to vitamin $A_{1}$ depleted rats. It has been found to be easily convertible to vitamin $A_{1}$, particularly in the gut wall.

\section{EXPERIMENTAL}

\section{Retinene $_{1}$}

Preparation and storage. Vitamin $\mathrm{A}_{1}$ aldehyde was prepared by the method of Ball et al. (1948). The material used had been purified by chromatography and contained about $\mathbf{7 5} \%$ of the pure substance, but unchanged vitamin $A_{1}$ could not be detected spectrophotometrically. It was stored as a solution in light petroleum at $0^{\circ}$ in the dark, under which conditions it was quite stable.

Solution in oil. A known quantity of refined ground-nut oil was added to a measured volume of the stock retinene solution in light petroleum. The volatile solvent was removed by warming under reduced pressure. The resulting solution in oil was used for oral administration.

Solution in propylene glycal. A similarly prepared solution in propylene glycol was administered intraperitoneally.

Determination. The amounts of retinene ${ }_{1}$ administered were determined by spectroscopic methods, using the absorption maxima at $368 \mathrm{~m} \mu$. (cyclohexane solution) and $664 \mathrm{~m} \mu$. ( $\mathrm{SbCl}_{3}$ colour test) following Ball et al. (1948). Similar methods using the ultraviolet maxima at $326 \mathrm{~m} \mu$. and the visible maximum at $617 \mathrm{~m} \mu$. ( $\mathrm{SbCl}_{3}$ colour test) were used for vitamin $A_{1}$. For the few extracts in which vitamin $A_{1}$ and retinene ${ }_{1}$ occurred together, the correction procedure of Morton \& Stubbs (1946) was applied to the ultraviolet absorption curves so as to determine both constituents.

\section{Animals}

Preparation for tests. Twenty-five newly weaned rats were depleted of vitamin $A_{1}$. Because of a shortage of rice starch, the diet low in vitamin $A_{1}$ which was previously used (Glover, Goodwin \& Morton, 1947 a) was modified by introducing boiled potatoes in place of rice starch. The cooked potatoes contained very small amounts of provitamin A (mainly as $\beta$-carotene). Careful analyses showed that each rat may have received the equivalent of $2-3$ i.u./day of provitamin A. The 